\title{
Nurses' Knowledge and Performance Related to Care of Children With Glucose -6- Phosphate Dehydrogenase Deficiency at Assiut University Children's Hospital
}

\author{
Asmaa Mohammed Abass, Khalid Ibrahim Abd-Alrhman Elsayh \& Amal Ahmad Mobarak \\ Nursing specialist in Assiut, Technical Institute of Nursing, Assiut University Egypt. \\ Assistant Professor of Pediatrics, Faculty of Medicine, Assuit University Egypt. \\ Lecturer of Pediatric Nursing, Faculty of Nursing, Assuit University Egypt.
}

\begin{abstract}
Background: Glucose -6- phosphate dehydrogenase (G6PD) deficiency is one of the most common genetic enzymes abnormalities leading to hemolytic anemia affecting more than 400 million children worldwide. Aim: this study aimed to assess nurses' knowledge and performance related to care of children with glucose-6- phosphate dyhydrogenase deficiency at Assiut Children University Hospital. Design: Descriptive research design was used in this study. Subjects and Method: The subjects who participated in this study included all nurses (45) working in the General Hematology unit (18),Private Hematology unit (8) and Emergency unit (19) at Assiut University Children's Hospital.Tools: a structured interview sheet and observational checklist were used to assess nurses' knowledge and performance. Results: It was found that more than half of nurses had unsatisfactory total score of knowledge and performance related to care of the children with G6PD deficiency. There were statistical significant relation between total score of nurses' knowledge, performance and their personal characteristics except the residence and place of work. Conclusion: Nurses knowledge regarding G6PD deficiency were not enough with some unsafe practices. Recommendation: Continuing nursing education and in-services training programs in general, special hematology and emergency units concerning glucose-6- phosphate deficiency have to be emphasized periodically.
\end{abstract}

Key words: Nurses', knowledge, Performance, Children \& Glucose -6- Phosphate Dehydrogenase Deficiency.

\section{Introduction}

Glucose-6-phosphate dehydrogenase deficiency (G6PDD) is a genetic disorder that occurs most often in males. The Glucose-6-phosphate dehydrogenase (G6PD) gene provides instructions for making an enzyme called Glucose-6-phosphate dehydrogenase. This enzyme is involved in the normal processing of carbohydrates. It also protects red blood cells from the effects of potentially harmful molecules called reactive oxygen species. As a result, reactive oxygen species can accumulate and damage red blood cells. Increasing the level of reactive oxygen species, causes red blood cells to be destroyed faster than the body can replace them. (http://www.ghr.nlm.nih, 2006).

Many other causes may trigger RBCs destruction as infections, severe stress and certain drugs, including: acetyl salicylic acid, chloramphincol and bimercopol.Hemolytic anemia can also occur after eating fava beans or inhaling pollen from fava plants (a reaction called favism). (Gregg \& Prchal, 2008).

The most common medical problem associated with glucose-6-phosphate dehydrogenase deficiency is hemolytic anemia. This type of anemia leads to paleness, yellowing of the skin and whites of the eyes (jaundice), dark urine, fatigue, shortness of breath, and a rapid heart rate. (Golan, 2007). Complication includes prolonged neonatal jaundice, kernicterus, life-threatening acute episodes of hemolysis, splenomegaly and acute renal failure (Zanella et al., 2005).

When a child has taken oxidative substances and suddenly shows the signs and symptoms of hemolytic anemia, he is said to have a hemolytic crisis. During such crisis, the role of nurses is to prevent the harmful effects from getting worse. Administration of blood transfusion is a must. Oxygen and folic acid have to be given. Once the trigger agent is removed or the child recovers from an illness and the child improves, nurses should provide further education to the child and his family about triggers and advise them that the child should avoid contact with those triggering agents. (Kyle, 2008).

A systematic physical assessment and measurement of baseline vital signs are important before transfusing blood. The respiratory system should be assessed, including careful auscultation of the lungs and the patient's use of accessory muscles. Cardiac system assessment should include careful inspection for any edema as well as other signs of cardiac failure (eg, jugular venous distention). The skin should be observed for rashes, petechiae, and ecchymoses. In the event of a transfusion reaction, a comparison of 
findings can help differentiate between types of reactions. (Hessig et al., 2004).

Significance of the study

Glucose-6-phosphate dehydrogenase deficiency (G6PDD) is the most common human genetic abnormalities, being present in more than 400 million children worldwide. The frequency of children admitted to Assiut University Children's Hospital suffering from acute hemolytic crisis caused by G6PD deficiency is about 150 children annually during the last three years. Children with G6PD deficiency are in need for special nursing care to minimize complication, such as, life-threatening acute episodes of hemolysis. Furthermore, result of this study could be helpful for health team professionals especially nurses in planning and implementing standards of nursing care for such group of patients in the future.

\section{Aim of the Study}

This study aims to assess nurses' knowledge and performance related to care of children with Glucose -6- Phosphate dehydrogenase deficiency at Assiut University Children's Hospital.

Research questions

- What are nurses' knowledge about care of children with G6PD deficiency?

- What are nurses' practice regarding care of children with G6PD deficiency?

\section{Subjects and methods}

\section{Researh hypothesis}

1. Nurses with old age had better knowledge and performance than new graduated nurses.

2. Nurses have more years of experience $\&$ attended training courses had better knowledge and performance than other nurses.

3. Highly educated nurses had better knowledge and performance than those graduated from technical schools.Subjects and Method

\section{Research design}

Descriptive research design was utilized to meet the aim of the study.

\section{Setting}

This study was conducted in the general Hematology, private Hematology Unit and emergency units at Assiut Children University Hospital.

\section{Subjects}

All nurses (45) working in the general Hematology Unit (18), the private Hematology Unit (8) and the Emergency Unit (19) at Assiut Children University hospital comprised the subject.

\section{Tools of data collection}

Two tools were used to collect the data.

Tool (1): Nurses' knowledge about G6PD deficiency structured questionnaire sheet.

This tol was developed by the researcher to assess nurses' knowledge about care of children with G6PD deficiency. It consisted of 2 parts:

Part one: Personal characteristics of the studied nurses such as: age, educational level, years of experiences, training courses, place of work, marital status and residence.

Part two: nurses' knowledge about care of children with Glucose -6- phosphate dehydrogenase deficiency such as the components of blood, level of child's red blood cells, level of hemoglobin of a child who need blood transfusion, definition of G6PD deficiency, causes, gender difference, signs and symptoms, diagnosis, complications, drugs and food avoided for children with G6PD deficiency and treatment.

Tool (2): Nurses' practice regarding care of children with G6PD deficiency. Observation checklist this tool was developed by the researcher to assess practice regarding care provided for children with Glucose -6- phosphate dehydrogenase deficiency (G6PD) deficiency it comprise the following (blood transfusion, oxygen therapy, hand washing, wearing gloves, donning gown and mask).

\section{Methods}

An official permission was obtained from the chairmen of Hematology and Emergency Units at Assuit University Children Hospital.

The study tools were developed by the researcher, after reviewing the relevant literature.

The validity was done for tools (I\&II) by five experts in pediatric field and its result was $94 \%$.

Internal consistency was measured by alpha Cronbach's test for (tool I) and its result was $\mathrm{R}=0.7$ and equivalence was measured for (tool II) by using interpreter (inter observer technique).

Pilot study It was carried out on $10 \%$ of the total nurses who were included in the study subjects, to test the clarity and visibility of the tools for doing the needed modification.

The researcher collected the needed data through distributing sheet (I). Sheet was distributed on nurses' throughout three shifts time was given to complete sheet filling and collected at the near end of the shift.

Each nurse was observed individually for her performance in the three shifts while caring children with G6PD deficiency using previous prepared checklist tool (II). The average time taken for observing each nurse was ranged from 45 minutes to 1 hour for procedures daily.

Data were collected during the period from the beginning of March 2012 to the end of August 2012. 


\section{Scoring system}

Tool (1): A structure questionnaire sheet: - it consisted of (20) questions

- Complete correct was given two marks, and the incomplete correct was given one mark and the incorrect was given zero.

- The total scoring of nurses' knowledge was done as follows:

Unsatisfactory $=$ less than $50 \%$.

Satisfactory $=50 \%$ and more.

Tool (II): observation checklist sheet: involved (86steps) for blood transfusion (39 steps), oxygen therapy (13 steps), hand washing (17 steps) and universal precaution ( wearing gloves 6 steps, wearing \& removing gown 8 steps and wearing mask

3 steps).

- The nurse obtained a score two marks for each step done complete, score (one) for done incomplete and score (zero) for not done.

- The total scoring of nurses' performance was done as follows

Unsatisfactory $=$ less than $50 \%$.
Satisfactory $=50 \%$ and more.

Ethical Considerations

1-Approval of the Ethical Committee in the Faculty of Nursing to conduct the research was done.

2-Written consent will be obtained from nurses to participate in the study.

3-Study subjects have the right to refuse to participate and or withdraw from the study without any rational at any time.

\section{Statistical analysis of the data}

Data entry and analysis were done by using SPSS program (statistical package for social science) version 16. Data were presented as number, percentage, mean and standard deviation. Chi square and fisher exact test were used to compare qualitative data. Correlation analysis was used for assessment of inter relationship between the total score of knowledge, performance and personal characteristics. Pearson correlation was used to measure correlation between score of knowledge and practice. $\mathrm{P}$ value considered statistically significant when $\mathrm{p}<0.05$.

\section{Results}

Table (1): Personal characteristics of the studied nurses. $(n=45)$.

\begin{tabular}{|c|c|c|}
\hline Characteristics & No. $(n=45)$ & $\%$ \\
\hline \multicolumn{3}{|l|}{ Age } \\
\hline$<25$ years & 13 & 28.9 \\
\hline $25-<30$ years & 14 & 31.1 \\
\hline$\geq 30$ years & 18 & 40.0 \\
\hline Mean \pm SD & \multicolumn{2}{|c|}{$29.00 \pm 7.18(19-45)$} \\
\hline \multicolumn{3}{|l|}{ Level of education } \\
\hline Nursing diploma & 33 & 73.3 \\
\hline Bachelor of nursing & 12 & 26.7 \\
\hline \multicolumn{3}{|l|}{ Years of experience } \\
\hline$<5$ years & 11 & 24.4 \\
\hline $5-10$ years & 14 & 31.1 \\
\hline$>10$ years & 20 & 44.4 \\
\hline \multicolumn{3}{|l|}{ Attending training programs } \\
\hline Yes & 1 & 3.0 \\
\hline No & 44 & 97.0 \\
\hline \multicolumn{3}{|l|}{ Place of work } \\
\hline Private hematology unit & 8 & 17.8 \\
\hline General hematology unit & 18 & 40.0 \\
\hline Emergency unit & 19 & 42.2 \\
\hline \multicolumn{3}{|l|}{ Marital status } \\
\hline Single & 5 & 11.1 \\
\hline Married & 40 & 88.9 \\
\hline \multicolumn{3}{|l|}{ Residence } \\
\hline Urban & 24 & 53.3 \\
\hline Rural & 21 & 46.7 \\
\hline
\end{tabular}

Vol , (3) No , (5) June 2015 
Table (2): Percentage distribution of the studied nurses according to their knowledge about Glucose-6phopsphate dehydrogenase deficiency (G6PDD) $(n=45)$.

\begin{tabular}{|c|c|c|c|c|c|c|}
\hline \multirow{2}{*}{ Items } & \multicolumn{2}{|c|}{ Complete correct } & \multicolumn{2}{|c|}{ Incomplete correct } & \multicolumn{2}{|c|}{ Incorrect } \\
\hline & No. & $\%$ & No. & $\%$ & No. & $\%$ \\
\hline Components of blood & 23 & 50.1 & 22 & 48.9 & 0 & 0.0 \\
\hline Level of child's red blood cells & 5 & 11.1 & 0 & 0.0 & 40 & 88.9 \\
\hline Level of child's hemoglobin need to blood transfusion & 12 & 26.7 & 0 & 0.0 & 33 & 73.3 \\
\hline Definition & 0 & 0.0 & 20 & 44.4 & 25 & 55.6 \\
\hline Causes & 0 & 0.0 & 36 & 80.0 & 9 & 20.0 \\
\hline Gender difference & 35 & 77.8 & 0 & 0.0 & 10 & 22.2 \\
\hline Signs of acute hemolytic anemia & 0 & 0.0 & 37 & 82.2 & 8 & 17.8 \\
\hline Symptoms of acute hemolytic anemia & 0 & 0.0 & 30 & 66.7 & 15 & 33.3 \\
\hline Diagnosis & 0 & 0.0 & 44 & 97.8 & 1 & 2.2 \\
\hline Complications & 0 & 0.0 & 27 & 60.0 & 18 & 40.0 \\
\hline Drugs avoided & 0 & 0.0 & 42 & 93.3 & 3 & 6.7 \\
\hline Foods avoided as fava beans & 0 & 0.0 & 30 & 66.7 & 15 & 33.3 \\
\hline Treatment & 1 & 2.2 & 34 & 75.6 & 10 & 22.2 \\
\hline
\end{tabular}

Table (3): Percentage total score of nurses' knowledge related to care of child with G6PD deficiency.

\begin{tabular}{|l|c|c|}
\hline \multicolumn{1}{|c|}{ Total score of knowledge } & No. $(\mathbf{n = 4 5})$ & \% \\
\hline Unsatisfactory $(<50 \%)$ & 28 & 62.2 \\
\hline Satisfactory $(\geq 50 \%)$ & 17 & 37.8 \\
\hline
\end{tabular}

Figure (1): Percentage total score of nurses' knowledge about G6PD deficiency.

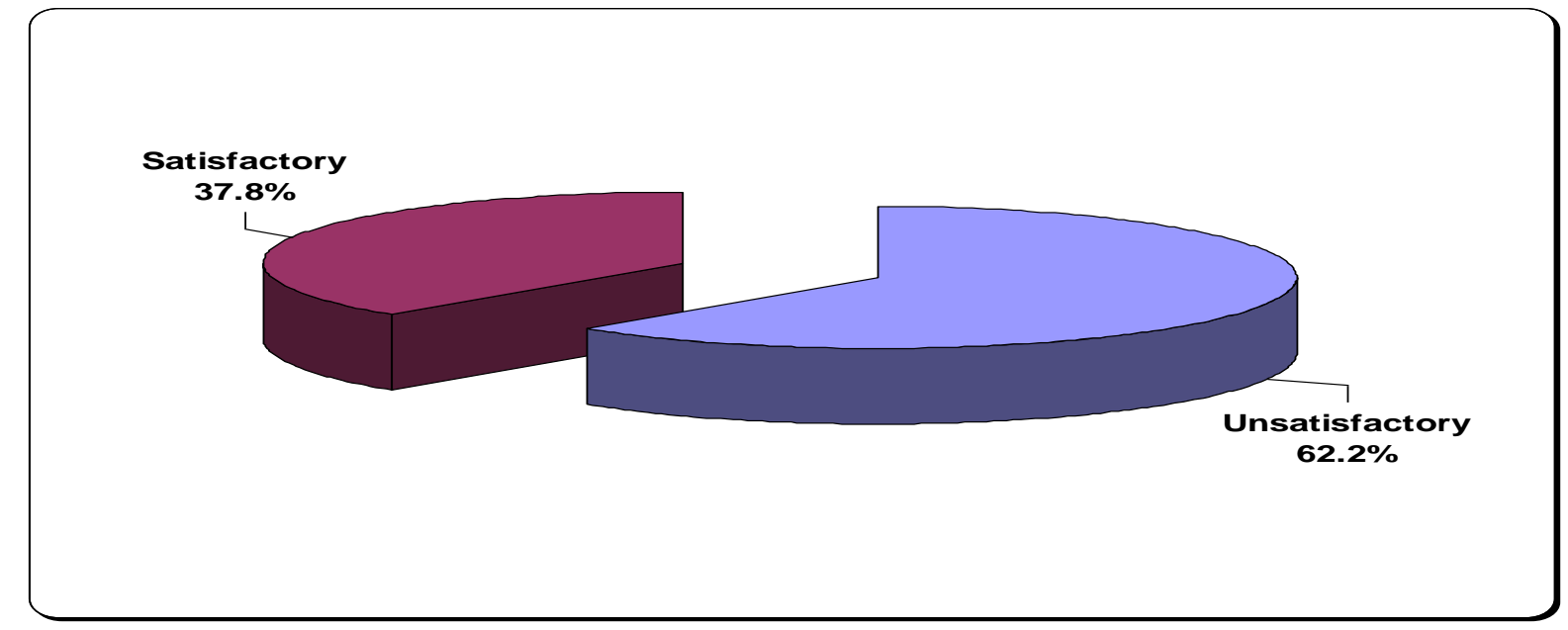

Table (4): Percentage score of nurses' performance related care of child with G6PD deficiency.

\begin{tabular}{|c|c|c|}
\hline Nurses' performance & No. $(\mathbf{n}=\mathbf{4 5})$ & Percent \\
\hline Blood transfusion & & 40.0 \\
\hline Unsatisfactory & 18 & 60.0 \\
\hline Satisfactory & 27 & 2.2 \\
\hline Oxygen therapy & 1 & 97.8 \\
\hline Unsatisfactory & 44 & \\
\hline Satisfactory & \multicolumn{2}{|}{} \\
\hline
\end{tabular}




\begin{tabular}{|c|c|c|}
\hline Nurses' performance & No. $(n=45)$ & Percent \\
\hline \multicolumn{3}{|l|}{ Hand washing } \\
\hline Unsatisfactory & 20 & 44.4 \\
\hline Satisfactory & 25 & 55.6 \\
\hline \multicolumn{3}{|l|}{ Universal precautions } \\
\hline Unsatisfactory & 36 & 80.0 \\
\hline Satisfactory & 9 & 20.0 \\
\hline
\end{tabular}

Table (5): Percentage of total score of nurses' performance related to care of child with G6PD deficiency.

\begin{tabular}{|l|c|c|}
\hline \multicolumn{1}{|c|}{ Level of performance } & No. $(\mathbf{n}=\mathbf{4 5})$ & Percent \\
\hline Unsatisfactory $(<50 \%)$ & 27 & 60.0 \\
\hline Satisfactory $(\geq 50 \%)$ & 18 & 40.0 \\
\hline
\end{tabular}

Figure (2): Percentage of total score of nurses' performance about G6PD deficiency.

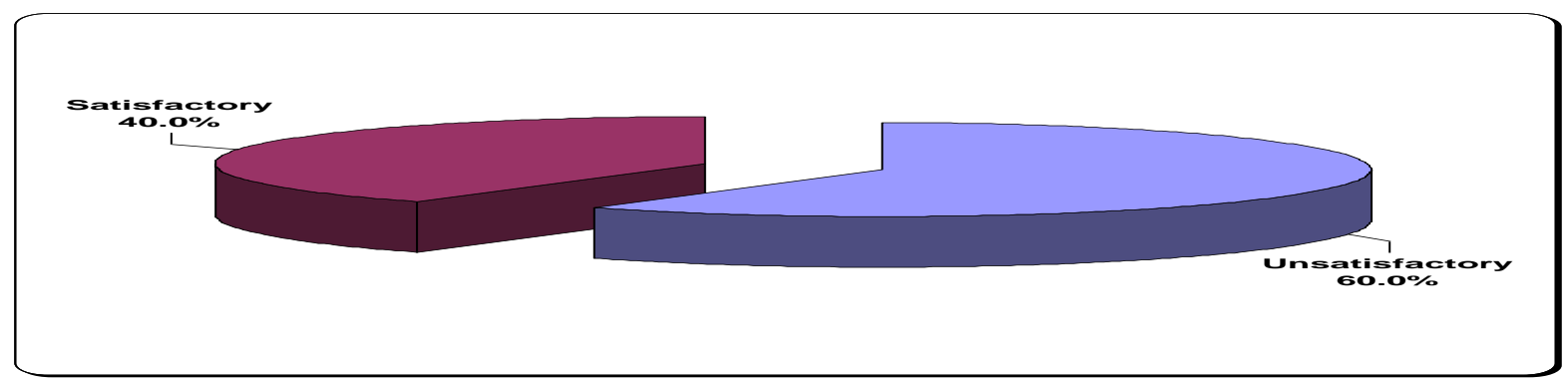

Table (6): Relation between nurses' personal characteristics and their total score of knowledge about G6PD deficiency.

\begin{tabular}{|c|c|c|c|c|c|c|}
\hline \multirow{3}{*}{ Personal characteristics } & \multicolumn{4}{|c|}{ Total score of knowledge } & \multirow{3}{*}{$\mathbf{X}^{2}$} & \multirow{3}{*}{ P-value } \\
\hline & \multicolumn{2}{|c|}{ Unsatisfactory $(n=28)$} & \multicolumn{2}{|c|}{ Satisfactory $(n=17)$} & & \\
\hline & No. & $\%$ & No. & $\%$ & & \\
\hline \multicolumn{5}{|l|}{ Age } & \multirow{4}{*}{11.90} & \multirow{4}{*}{$0.003^{*}$} \\
\hline$<25$ years & 12 & 92.3 & 1 & 7.7 & & \\
\hline $25-<30$ years & 10 & 71.4 & 4 & 28.6 & & \\
\hline$\geq 30$ years & 6 & 33.3 & 12 & 66.7 & & \\
\hline \multicolumn{5}{|l|}{ Qulification } & \multirow{3}{*}{7.61} & \multirow{3}{*}{$0.006^{*}$} \\
\hline Nursing diploma & 25 & 75.8 & 8 & 24.2 & & \\
\hline Nursing bachelor & 3 & 25.0 & 9 & 75.0 & & \\
\hline \multicolumn{5}{|l|}{ Years of experience } & \multirow{4}{*}{3.47} & \multirow{4}{*}{$0.014^{*}$} \\
\hline$<5$ years & 10 & 90.9 & 1 & 9.1 & & \\
\hline $5-10$ years & 10 & 71.4 & 4 & 28.6 & & \\
\hline$>10$ years & 8 & 40.0 & 12 & 60.0 & & \\
\hline \multicolumn{5}{|l|}{ Place of work } & \multirow{4}{*}{5.94} & \multirow{4}{*}{0.051} \\
\hline Private hematology unit & 8 & 100.0 & 0 & 0.0 & & \\
\hline General hematology unit & 10 & 55.6 & 8 & 44.4 & & \\
\hline Emergency unit & 10 & 52.6 & 9 & 47.4 & & \\
\hline \multicolumn{5}{|l|}{ Residence } & \multirow{3}{*}{1.62} & \multirow{3}{*}{0.203} \\
\hline Urban & 17 & 70.8 & 7 & 29.2 & & \\
\hline Rural & 11 & 52.4 & 10 & 47.6 & & \\
\hline
\end{tabular}

*Statistically significant differences $P<0.05$ 
Table (7): Relation between nurses' personal characteristics and their total score of performance about G6PD deficiency.

\begin{tabular}{|c|c|c|c|c|c|c|}
\hline \multirow{3}{*}{ Personal characteristics } & \multicolumn{4}{|c|}{ Level of performance } & \multirow{3}{*}{$\mathbf{X}^{2}$} & \multirow{3}{*}{ P-value } \\
\hline & \multicolumn{2}{|c|}{$\begin{array}{c}\text { Unsatisfactory } \\
(n=27)\end{array}$} & \multicolumn{2}{|c|}{$\begin{array}{l}\text { Satisfactory } \\
(n=18)\end{array}$} & & \\
\hline & No. & $\%$ & No. & $\%$ & & \\
\hline \multicolumn{5}{|l|}{ Age } & \multirow{4}{*}{8.43} & \multirow{4}{*}{$0.015^{*}$} \\
\hline$<25$ years & 10 & 76.9 & 3 & 23.1 & & \\
\hline $25-<30$ years & 4 & 28.6 & 10 & 71.4 & & \\
\hline$\geq 30$ years & 13 & 72.2 & 5 & 27.8 & & \\
\hline \multicolumn{5}{|l|}{ Qulification } & \multirow{3}{*}{8.35} & \multirow{3}{*}{$0.004 *$} \\
\hline Diploma degree in Nursing & 24 & 72.7 & 9 & 27.3 & & \\
\hline Bachelor degree in Nursing & 3 & 25.0 & 9 & 75.0 & & \\
\hline \multicolumn{5}{|l|}{ Years of experience } & \multirow{4}{*}{8.44} & \multirow{4}{*}{$0.000 *$} \\
\hline$<5$ years & 10 & 90.9 & 1 & 9.1 & & \\
\hline $5-10$ years & 2 & 14.3 & 12 & 85.7 & & \\
\hline$>10$ years & 15 & 75.0 & 5 & 25.0 & & \\
\hline \multicolumn{5}{|l|}{ Place of work } & \multirow{4}{*}{0.784} & \multirow{4}{*}{0.676} \\
\hline Private hematology unit & 5 & 62.5 & 3 & 37.5 & & \\
\hline General hematology unit & 12 & 66.7 & 7 & 33.3 & & \\
\hline Emergency unit & 10 & 52.6 & 9 & 47.4 & & \\
\hline \multicolumn{5}{|l|}{ Residence } & \multirow{3}{*}{0.73} & \multirow{3}{*}{0.393} \\
\hline Urban & 13 & 54.2 & 11 & 45.8 & & \\
\hline Rural & 14 & 66.7 & 7 & 33.3 & & \\
\hline
\end{tabular}

Statistically significant differences $P<0.05$

Figure (3): Correlation between total score of studied nurses' knowledge and performance.

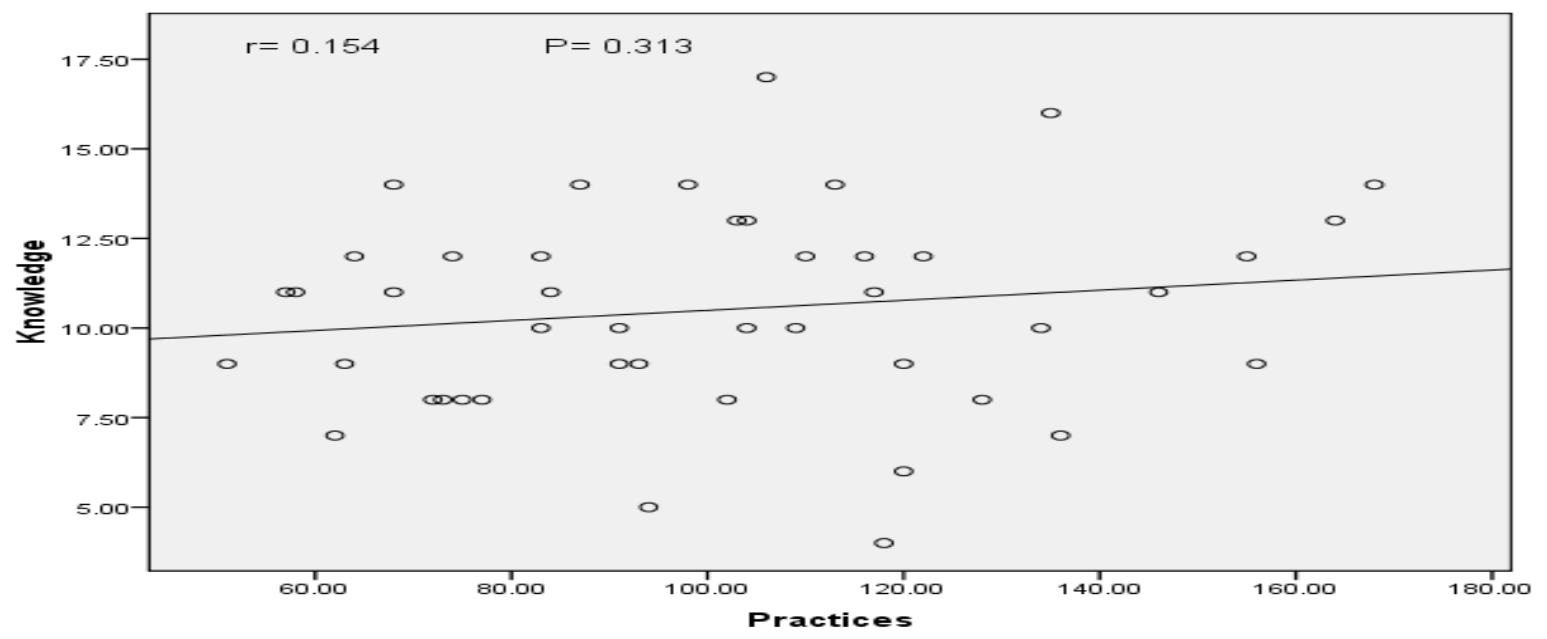

Table (1): Presents the personal characteristics of the studied nurses. It was observed that $40.0 \%$ of the studied nurses aged 30 years and more. More than one quarter of them (28.9\%) aged less than 25 years with a mean age $29.00 \pm 7.18$. About three quarters of nurses had diploma degree in Nursing $(73.3 \%)$ and $26.7 \%$ of them had nursing bachelor degree. As for years of experience, the table shows that $(24.4 \%)$ of the studied nurses had less than 5 years,
$(31.1 \%)$ of them had $5-10$ years and $(44.4 \%)$ of them had more than 10 years of experience. Regarding Glucose -6- phosphate dyhydrogenase deficiency (G6PD) deficiency training programs, only $3 \%$ of the studied nurses were attended. As regard the place of work, it was found that nurses who are working in the private Hematology Unit, the general Hematology and the Emergency units constituted $17.8 \%, 40.0 \%$ \& $42.2 \%$ of them, respectively. The majority of studied 
nurses were married (88.9\%) and $53.3 \%$ of them were coming from the urban area.

Table (2) : It shows the percentage distribution of the studied nurses according to their knowledge about G6PD deficiency. It was noticed that none of nurses had incorrect knowledge about blood components. The minority of studied nurses (11.1\%) had completed correct knowledge about level of child's red blood cells. Concerning level of child's hemoglobin that require blood transfusion, it was observed that less than one third of the studied nurses (26.7\%) had complete correct knowledge while $(73.3 \%)$ of them had incorrect knowledge. As regards definition, causes, sings\& symptoms, diagnosis, complications and drugs\& foods avoided for children with G6PD deficiency, it was noticed that no one of studied nurses' $(0.0 \%)$ had completed correct knowledge. More than three quarters of the studied nurses $(77.8 \%)$ had completed correct knowledge, concerning gender differences, as well as $(2.2 \%)$ of them had complete correct knowledge and more than three quarter of them $(75.6 \%)$ had incomplete correct knowledge about treatment of G6PD deficiency.

Table (3): shows percentages total score of nurses' knowledge related care of child with G6PD deficiency. It was found that more than half of nurses $(62.2 \%)$ had unsatisfactory knowledge while $37.8 \%$ of them had satisfactory knowledge about G6PD deficiency.

Table (4): shows percentages total score of nurses' performance related to care of child with G6PD deficiency. It was observed that more than half of nurses $(60.0 \%)$ had satisfactory performance about blood transfusion. Concerning oxygen therapy, it was observed that great majority of nurses $(97.8 \%)$ had satisfactory performance. As regards hand washing, it was noticed that $55.6 \%$ of nurses' had satisfactory performance. While $80.0 \%$ of them had unsatisfactory performance about universal precaution.

Table (5): shows percentages total score of nurses' performance related to care of child with G6PD deficiency. It was observed that more than half of nurses $(60.0 \%)$ had unsatisfactory performance, while $40.0 \%$ of them had satisfactory performance related to care of child with G6PD deficiency.

Table (6): illustrate the relation between nurses' personal characteristics and their total score of knowledge about G6PD deficiency. Statistical significant difference was found between nurses age and their total score of knowledge $\left(\mathrm{X}^{2}=11.90 \& \mathrm{P}-\right.$ value $=0.003)$. It was shown that $66.7 \%$ of nurses who aged equal 30 years \& more had satisfactory knowledge compared to $28.6 \%$ of them who aged from 25 years to less than 30 years and $7.7 \%$ of them who aged less than 25years $\mathrm{P}=0.003$. Statistically significant difference was illustrated between nurses qualifications and their total score of knowledge $\left(\mathrm{X}^{2}=\right.$ $7.61 \& \mathrm{P}-$ value $=0.006)$. It was observed that three quarters of nurses who had baccalaureate degree in nursing $(75.0 \%)$ had satisfactory knowledge compared to nurses who had diploma degree in nursing $(24.2 \%)$. Statistically significant difference was found between nurses' years of experience and their total score of knowledge $\left(\mathrm{X}^{2}=3.47 \& \mathrm{P}\right.$ - value $=0.014)$. It was found that $60 \%$ of nurses who had years of experience more than 10 years had satisfactory knowledge. No statistical significant difference was found between the place of work, nurses' residence and their total score of knowledge about G6PD deficiency.

Table (7): It shows the relation between nurses' personal characteristics and their total score of performance about care of child with G6PD deficiency. Statistically significant differences was found between nurses' age and their total score of performance $\left(\mathrm{X}^{2}=8.43 \& \mathrm{P}-\right.$ value $\left.=0.015\right)$. It was shown that $71.4 \%$ of nurses who aged from 25 years to less than 30 years had satisfactory performance than nurses who aged equal to 30 years \& more, $23.1 \%$ of them who aged less than 25 years, $\mathrm{P}=$ 0.015. Statistically significant differences was illustrated between nurses qulifications and their total score of performance $\left(\mathrm{X}^{2}=8.35 \& \mathrm{P}\right.$ - value $\left.=0.004\right)$. It was observed that three quarters of nurses with baccalaureate degree $(\mathbf{7 5 . 0 \% )}$ had satisfactory performance compared to nurses had diploma degree $(27.3 \%)$ of nurses who had diploma degree in nursing $\mathrm{P}=0.004$. Statistically significant difference was observed between nurses' years of experience and their total score of performance, majority of nurses $(85.7 \%)$ who had years of experience 5-10 years had satisfactory performance. No statistically significant difference were found between the place of work, residence and nurses' total score of performance related to care of child with G6PD deficiency e.

Figure (3): showed no correlation between total score of studied nurses' knowledge and performance.

\section{Discussion}

Enzymes are proteins that help to regulate biochemical reactions and metabolism in the body and cells. In the case of red blood cells, glucose-6phosphate dehydrogenase (G6PD) is a very important enzyme. It keeps red blood cells healthy so they can function properly and live a normal life span of approximately 120 days. Too little G6PD leads to the destruction of red blood cells. This process is called hemolysis. When this process is actively occurring, it 
is called a hemolytic episode. Dowshen\& Steven, (2009).

Based on the results of the present study, it was found that, majority of them have diploma degree in nursingnursing, married and $40 \%$ of them aged $30 \mathrm{yrs}$ or more and this agree with Hassan et al., (2010) study who stated that the majority of the nurses were married, females, and had diploma of nursing. This study disagrees with Gadallah et al., (1998) study who stated that the majority of the nurses aged from 20- to less than 30 years.

As regard years of experience, it was noticed that less than half of nurses had experience more than 10 years. Ahamed et al., (2010) was in the same line with the current study findings conducted a study in hemodialysis unit of Assiut University Children Hospital, entitled developing the designed protocol regarding the care offered to hemodialysis patients revealed that less than half of them had an experience more than ten years. This study disagrees with Hassan et al., (2010) study who stated that the majority of the studied nurses' experiences ranged from 5 to less than 10 years. This also disagrees with Gadallah et al., (1998) study who stated that the majority of nurses had experience rang from 1 to less than5 years.

Marquis and Huston, (2009) stated that education and training are two components of staff development that occur after an employees' indoctrination (which refers to planned, guided adjustment of employee to the organization and work environment). The staffs' knowledge level and capabilities are a major factor in determining the number of staff required to carry out unit goals. The better trained and more competent the staff, the fewer the staff required, which in turn saves the organization money and rise reproductively.

As regard attending training courses, it was found that the great majority of studied nurses didn't attend training courses related to Glucose-6- phosphate dehydrogenase deficiency (G6PDD). This may be attributed to their hospital focus on courses related to infection control rather than courses related to G6PD deficiency. This result agrees with Hassan et al., (2010) who stated that study in which the majority of them have no in-service training courses related to dialysis. Also this study agrees with Gadallah et al., (1998) study in which more than half of studied nurses' didn't attend any training programs.

Regarding total percent score of nurses' knowledge about G6PD deficiency, it was noticed that nearly two third of nurses had unsatisfactory knowledge related to care of child with G6PD deficiency that's related to lack of updating knowledge, availability of suitable educational materials and refreshing courses. They did not attend any organization program to improve their knowledge about G6PD deficiency as well as lack of educational preparation for the majority of them. This result agrees with Ahmed et al., (2005) who reported that most of the nurses had low knowledge related to care of child. On the contrary, results of the present study were inconsistent with Ali et al., (2011) who stated that the studied nurses were better in their total percent score of knowledge. This also disagrees with Paudya et al., (2008) who stated that the majority of nurses had good scores of knowledge.

Regarding nurses' performance regarding G6PD deficiency, it was noticed that unsatisfactory of performance was recognized among less than two third of nurses. That is related to inadequate of resources in the unit and this finding may be because the organization and profession did not set standards and objectives to guide nurses in performing safe and effective care. This result agreed with Shimokura, et al., (2006) who found that nurses' knowledge was very poor related to all areas of performance. Moreover, this finding also agreed with Ahmed et al., (2005) who reported that nurses had low score in their performance related to care of children.

This result also agreed with Grerdiz and Bucknall, (2000) who reported that over half of the nurses who participated in this study and who worked in the intermediate care units had low level performance. In contrast Elsayed, et al., (2008) found that the total average percentage of nurses' performance was good. Concerning the factors influencing nurses' knowledge and performance, in this study, it was found that the nurses' level of education may have its effect on their knowledge and performance Statistical significant relation was found between nurses' knowledge and performance and their level of education, however the percentage of satisfactory knowledge and performance was higher in nurses with bachelor degree. In atrial to explain the previous results, we suggest that bachelor degree nurses study subjects related to G6PD deficiency in their curriculum. These results highlight the importance of applied education that indicated by a graduate degree as significant positive predicator in providing advanced clinical skills for practice. This finding was in agreement with Mohamed et al., (2010) who reported that nurses' knowledge and practice are affected by their level of education.

Nurses' age might be a factor as it plays a vital role in improving the nurses' knowledge. The present study showed a significant relation between total score of nurses' knowledge and their age. These results were in agreement with Said, (2004) who stated that higher rates of nurses who had satisfactory level of knowledge were older than nurses who had low knowledge score. This is in contrast with Ali et al., 
(2011) who stated that the nurses aged less than 20 years had excellent score of knowledge. Also these results disagreed with Hassanet al., (2010) who stated that there was no statistical significant difference between nurses' knowledge score and their age group pre implementing designed nursing protocol on nurses' knowledge and practice regarding Hemodialysis patients.

The present study showed a statistical significant difference between total score of nurses' knowledge with their duration of experience and this is in the same line with Hassan et al., (2010) who stated that there is statistical significant difference between score nurse's knowledge and their duration of experience. Also this result agreed with Ahmed et al., (2005) who reported that nurses with experience of 2 years and more had correct knowledge more than nurses who had experience of less than 2 years.

These results disagreed with those of Azer et al., (2005) and Gadallah et al., (1998) who reported that total scores of nurses' knowledge in relationship to their years of nurses' experience showed that the newly graduate nurses had correct knowledge more than the old nurses. This also disagreed with Ali et al., (2011) who stated that the nurse who had less than five years of experience had excellent score of knowledge (32.4\%). Also Gamal et al., (2005) who found the youngest nurses with less than one year experience had more knowledge than older nurses with more experience.

The results of this study revealed that satisfactory performances levels were higher among nurses aged $25-<30$ years. This may be because older nurses depend on younger nurses in work and they prefer to play administrative role only. This agreed with Ali et al., (2011) who stated that the young aged nurses, who are more active, initiative, has good physical fitness and creative in achieving nursing skills. In contrast Said, (2004) who found that higher rates of nurses' who had satisfactory level of performance existed among the older age of nurses'.

Also the results showed that satisfactory performance levels were higher among nurses who had years of experience ranged from 5 to 10 years than those who had work experience more than 10 years This might be explained that nurses had more years of experience were responsible for administrative and managerial activities. While younger ones have more practical work in direct patient care. These agreed with Azer, (2005) who reported that new nurses had a score of performance higher than older nurses. On the same line Gamal et al., (2005) who found that the youngest nurses with less than one year experience had better practice than older nurses with more experience.
In contrast with Gadallahet al., (1998) who stated that nurses with more years of experience had higher rate of performance than other nurses. Also this disagrees with Ali, (2011) who showed that the nurse who had less than five years of experience had accepted performance.

The results of the present study were inconsistent with National Institute for clinical Excellence, (2000) which stated that nurses with many years of experience may require a minimum of additional instruction before they are ready to take a patient assignment, nurses with years of experiences in one clinical specialty may need a moderate amount of instruction to acquire through training program.

The results of the present study showed that there is no statistically significant difference between nurses' knowledge and their practice. This may be attributed to insufficient courses related to (G6PD) deficiency included in their undergraduate curriculum of nursing education, refresher courses after their work and also there is no available Arabic source for updating and continuing their education. This result agreed with Hassanet al., (2010) who stated that there is no significant difference between nurses' knowledge and their practice observed during the pre-implementing designed nursing protocol on nurses' knowledge and practice regarding Hemodialysis patients'.

\section{Conclusions}

Based on the results of this study, it can be concluded that

- The total score of nurses' knowledge and performance related to care of children diagnosed with Glucose -6- Phosphate dehydrogenase deficiency at Assuit Children University Hospital were incomplete with some unsafe performance.

- There was also no correlation between total scores of nurses' knowledge and their performance.

- The more the years of experience, the age and the educational level of nurses, the higher the rate of satisfactory knowledge.

- Statistical significant difference was found between nurses' performance \& their age, years of experience and level of education.

\section{Recommendations}

Based on results of the present study it can be recommended that:

1. Replication of the study on a larger probability sample acquired from different geographical areas in Egypt to figure out the main aspects of this problem.

2. Continued nursing education and in-services training programs in general, special hematology and emergency units should be well organized 
within Assiut University Children Hospital and equipped with the necessary educational facilities and materials necessary to upgrade the knowledge and skills of practicing nurses.

3. Nurses should add to their routine obligations the regular reading of up-to-date references (periodicals, textbooks, etc.). They should always be encouraged to attend scientific meetings and conferences to keep pace with the rapidly growing wealth of knowledge and practice necessary for proper nursing service.

4. Periodic monitoring of nurses knowledge and practice to evaluate their level.

5. Availability of manual procedures for nurses to be aware of handling any problems that may arise.

\section{References}

1. Ahmed F., Ali F., Ahmed A. \& Abdelkreem H., (2005): A study of assessment of nurses' performance and knowledge at Assiut hospitals. Unpublished master Thesis, Faculty of Nursing, Pediatric Nursing Department, Faculty of Nursing, Assiut University.

2. Ahmed G., Sobhi M. \& Mohamed Z., (2011): Effect of designed nursing protocol on nurses knowledge and practice regarding hemodialysis patients at Assiut hospitals. Unpublished master Thesis. Faculty of Nursing, Adult Nursing Department, Assiut University.

3. Ali A., Essawy M., kamel M., Abdelkreem H. \& Gadallah M., (2011): Knowledge and performance of health team about infection control in the neonatal intensive care units at Assiut and El Minia university hospitals. Unpublished doctoral thesis, Pediatric Nursing Department, Faculty of Nursing, Assiut University.

4. Azer S., Sobhi M., \& Mohamed Z., (2005): A study of factors affecting nurses' performance. Master thesis, B.Sc. Nursing, Adult Nursing department, Faculty of nursing, Assiut University.

5. Dowshen M., \& Steven (2009) : G6PD Deficiency, Kids Health. Available at: http://kidshealth.org/parent/general/aches/g6pd.h tml

6. Elsayed E., Zahran S., \& Elawany T., (2008): Effect of educational intervention of nurses performance to control infection in neonatal intensive care unit Tanta university hospital, Bulletin of high institute of public health; 38(3), P.1012.

7. Gadalla M., Abedelmoiz A., \& Ahmed A., (1998): A., study of assessment of nurses' performance and knowledge related to care of newborn with hyperbilirubinemia at Assiut hospitals, Master thesis, B.Sc. Nursing, Pediatric Nursing Department, Faculty of nursing, Assiut University.

8. Gamal L., Mohamed K., Mohamed R., \& Shawer O., (2005) : Establishing standards for prevention of nosocominal infection in the recovery rooms and surgical ward at Elminia University Hospital. Unpublished doctoral thesis. Faculty of Nursing, Assiut university.

9. Golan D., (2007) : Hemolytic anemias. In: Goldman L, Ausiello D, Cecil Medicine, $23^{\text {rd }}$ ed, chp 165, Philadelphia, Pa: Saunders Elsevier Mosby, Pp.1120-1121.

10. Gregg X., \& Prchal J., (2008) : Hematology: Basic Principles and Practice, red blood cell enzymopathies. In: Hoffman R, Benz Jr. EJ, Shattil SJ, et al, $5^{\text {th }}$ ed, chp 45 , Mosby company, Philadelphia, Pp.503, 510.

11. Grerdiz M.. \& Bucknall T., (2000) : Australian triage nurses' knowledge and scope practice. Aust. J. Adv Nurse, 18 (1), Pp. 24-33.

12. Hassan A., Hassanein F., \& Gadallah M., (2010): Risk factor of neonatal sepsis in neonatal intensive care unit (NICU) at assiut university children hospital. Master Thesis, Pediatric Nursing Department, Faculty of nursing, Assiut University, P. 90.

13. Hessig R., Arcand L., \& Frost M., (2004) : The effects of an educational intervention on oncology nurses attitude, perceived knowledge, and self-reported application of complementary therapies. Oncology Nursing Forum, 31(1), Pp.71-72.

14. http://www.ghr.nlm.nih.gov/condition/glucose -6-phosphate-dehydrogenasedeficiency, (2006).

15. Kyle T., (2008) : Essentials of pediatric nursing, Glucose-6-phosphate dehydrogenase, $3^{\text {rd }}$ ed, chp 11, Lippincott Williams\& Wilkins Company, London, Pp. 891-892.

16. Mohamed F., Ibrahim H., \& Mohamed S., (2010): Knowledge practice and attitude of nurses toward universal precaution in outpatient clinics at assiut university hospitals. Master Thesis, Community Health Department, Faculty of Nursing, Assiut University.

17. Marquis L., \& Huston J., (2009) : Leader ship roles and management functions in nursing, $6^{\text {th }}$ ed, chp 9, Lippincott, Hong Kong, Pp.371, 375.

18. National institute for clinical excellence, (2000) : Published in the internet from http://www.nice.org.UK/Clin-guide/clingud main.html.

19. Paudya I., Simkhada P., \& Bruce J.,(2008): Infection control knowledge, attitude and 
practice among Nepalese health care workers. American Journal of infection control, 36 (8) Pp. 595-596.

20. Said H., (2004) : Knowledge and Practices of Nurses regarding Hand washing and Use of Gloves in Patient's Wards in Alexandria Hospitals. Unpublished Master Thesis. High Institute of Public Health University of Alexandria.

21. Shimokura G., Weber D., Miller W., Wurlzel H., \& Alter M., (2006): Factors associated with personal protection equipment use and hand hygiene among hemodialysis staff.Infect.control, 34 (3) P.100.

22. Zenella A., Bianchi P., Fermo E., Valentini G., (2005) : Glucose-6-phosphate dehydrogenase deficiency: Molecular and clinical aspects. $\mathrm{Br} \mathrm{J}$ Haematol, P. 130, 11-25. 